\title{
Synthesis of model DNA and their application as substrates of nucleotide excision repair
}

\author{
A. N. Evdokimovi , A. Yu. Tsidulko, , I. O. Petruseva ${ }^{1}$, L. S. Koroleva ${ }^{1,2}$, \\ I. Yu. Serpokrylova ${ }^{1}$, V. N. Silnikov ${ }^{1}$, O. I. Lavrik ${ }^{1,2}$ \\ ${ }^{1}$ Novosibirsk Institute of Chemical Biology and Fundamental Medicine, Siberian Branch of the Russian Academy of Sciences \\ 8, Akademika Lavrentieva Ave., Novosibirsk, Russian Federation, 630090 \\ ${ }^{2}$ Novosibirsk State University \\ 2, Pirogova Str., Novosibirsk, Russian Federation, 630090 \\ an_evdokimov@mail.ru
}

\begin{abstract}
Aim. Nucleotide excision repair (NER) is DNA repair system responsible to remove bulky lesions from DNA. These lesions appear in DNA as consequence of UV-light irradiation or environmental stress. Study of NER is extremely important to improve action of chemotherapeutic drugs. Methods. In vitro NER-assay and photoaffinity modification were used. Results. Long linear DNA analogs mimicking NER substrates have been synthesized. DNA analogs are 137-mer duplexes containing in their internal positions nucleotides with bulky substitutes imitating lesions with fluorochloroazidopyridyl and fluorescein groups introduced using spacer fragments at the $4 N$ and $5 C$ positions of $d C M P$ and $d U M P(F a p-d C$ - and Flu-dU-DNA) and DNA containing a (+)-cis-stereoisomer of benzo[a]pyrene-N2-deoxyguanosine (BP-dG-DNA). The interaction of the modified DNA duplexes with the proteins of NER-competent HeLa extract was investigated. The substrate properties of the model DNA in the reaction of specific excision were shown to vary in the row Fap-dC-DNA $<<F l u-d U-D N A<B P-d G-D N A$. Conclusions. In vitro assay show that DNA analogs represent an interesting tool for the estimation of cellular repair activities. The developed approach should be of general use for the incorporation of NER-sensitive distortions into model DNA and seems to be very promising for repair mechanism studies.
\end{abstract}

Keywords: nucleotide excision repair, model bulky substituted DNA substrates.

Intoduction. In eukaryotic cells, the nucleotide excision repair (NER) is performed through coordinated action of multicomponent protein complexes of variable composition that are sequentially assembled in a damaged DNA region. The main NER enzymes and protein factors have been identified, but the architecture of specific protein-nucleic acid complexes, the mechanism of their functioning, and interaction of their components are still subjects of active investigation.

NER system recognizes and removes from DNA a wide variety of structurally diverse helix-distorting bulky adducts. Such lesions appear as a result of exposure of DNA to various physical or chemical factors (UV or ionizing radiation, environmental pollutants, chemotherapeutic agents, etc.). During eukaryotic NER a region with damaged link (24-32 nucleotides) is removed from

(C) Institute of Molecular Biology and Genetics, NAS of Ukraine, 2012
DNA followed by reconstruction of the nucleotide sequence using an undamaged DNA chain as a template for the reparative synthesis [1-3].

NER is characterized by broad substrate specificity. However, the rates of repair of structurally similar lesions may be substantially different. The efficiency of removal of the DNA region with a damaged nucleotide estimated using model substrates, in combination with the results of analysis of interaction between substrate analogs and NER proteins, provides information on the details of lesion recognition by NER system.

Many biochemical approaches to NER investigation are based on synthetic substrate analogs, i. e. double-stranded DNA bearing modification in the defined position of the molecule, and structural analogs of the intermediates that appear during NER [4-8]. This fact determines the interest in development and improvement of methods of model lesions synthesis and crea- 
tion of synthetic DNA on their basis. It is known that a model lesion must be included in long DNA for the formation of functional NER complexes [9]. In some works, substrate properties were studied using circular structures based on a phage or plasmid DNA and bearing lesions in the target position (or positions) or statistically introduced into the DNA molecule at a particular frequency. This approach demands sufficient efforts to be applied.

Another type of model structures being substrates of the eukaryotic NER system is linear DNA duplexes of $>120 \mathrm{bp}$ in length bearing a modified nucleotide in an internal position of the chain at approximately equal distances from the ends of the duplex [10]. The use of long DNA analogs of substrates containing regions of several unpaired bases, including those introduced at a distance from the lesion, made it possible to specify the role of the undamaged chain in lesion recognition and to confirm the hypothesis of a two-stage (or bipartite) $[11,12]$ mechanism of lesion recognition. For instance, it has been shown that the efficiency of repair of model DNA containing hard-to-repair cyclobutane pyrimidine dimers noticeably increases on introduction of a bubble or a loop of three unpaired bases in size on the 5'-side of the lesion [12]. Besides, it was recently shown by the example of long linear DNA containing a benz[a]pyrene modification that lesion recognition by NER proteins and efficiency of lesion removal depend not only on the type of modification introduced but also on details such as differences in the spatial structure of the lesion [13] and sequence of the regions flanking the lesion [14].

The goal of the present work was to create long linear DNA analogs of NER substrates and then to analyze their interaction with proteins of cell extracts containing a complex of NER proteins and to estimate the properties of the created model DNA as substrates of the NER.

Materials and methods. Fluorescein-5(6)-carboxamidocaproyl-[5-(3-aminoallyl)-2'-deoxyuridine-5'triphosphate] (Flu-dUTP) was from Biosan (Novosibirsk). Exo- $N$ - $\{2-[\mathrm{N}$-(4-azido-2,5-difluoro-3-chloropyridine-6-yl)-3-aminopropionyl]aminoethyl $\}$-2'-deoxycytidine-5'-triphosphate (Fap-dCTP) was synthesized as described in [15] and kindly provided by S. V. Dezhurov. Deoxyribooligonucleotide containing (+)cis-benzo[a]pyrene-N2-deoxyguanosine (BP-dG) has been kindly provided by N. E. Geatsintov (New York University, USA).

Deoxyribooligonucleotides (ONT) and $\left[\alpha-{ }^{32} \mathrm{P}\right] \mathrm{dCTP}$ $(3000 \mathrm{Ci} / \mathrm{mmol})$ produced at the Institute of Chemical Biology and Fundamental Medicine, Siberian Branch of the Russian Academy of Sciences.

Proteins preparation. NER-competent extract of HeLa cells was obtained by the method described in [10]. Recombinant heterodimer XPC-HR23B (FlagXPC and in 6His-Tag-HR23B) was obtained by the method described in [16] with slight modifications.

Synthesis of model DNA was described in details in [17]. Base substituted dNTP analogs (Fap-dCTP and Flu-dUTP) were used as substrates of DNA polymerase to introduce modified dNMP moiety into the 3'-end of ONT. Long modified ONT was synthesized using ligation of modified 5'-component with radioactively labeled 3'-component as described earlier [17].

For the formation of model DNA duplexes modified long ONT and complementary unmodified ONT were annealed.

The BP-modified DNA chain was obtained by ligation of 11-nt 5-[ $\left.{ }^{32} \mathrm{P}\right]-\mathrm{ONT}$, bearing BP-dG and flanking ONTs.

In vitro NER assay. The efficiency of removal of DNA region containing model lesions was described in details in [17] and determined using both direct and indirect («fill-in») methods. For direct detection reaction mixtures containing of internally labeled model DNA duplexes were incubated with NER-competent cell extract. $1 \times$ NER buffer $(25 \mathrm{mM}$ Hepes, $\mathrm{pH} 7.8,45 \mathrm{mM}$ $\mathrm{NaCl}, 4.4 \mathrm{mM} \mathrm{MgCl} 2,0.1$ mM EDTA, 4 mM ATP. Reaction mixtures were analyzed by electrophoresis in polyacrylamide gel under denaturing conditions followed by quantitative autoradiography. Quantitative analysis was done relatively to total radioactivity in each lane, using control lane signal as baseline.

For «fill-in» synthesis reaction mixtures was additionally contain the template 5'-gggggctcggcaccgtcacc ctggatgctgtagg-p-3', and the model DNA duplex was unlabeled. After incubation with NER-competent cell extract, radioactive label was introduced into excised DNA fragments using $\left[\alpha-{ }^{32} \mathrm{P}\right] \mathrm{dCTP}$ as substrate of DNA polymerase reaction.

The effect of Fap-dC- and Flu-dU-DNA on the level of specific excision from [ $\left.{ }^{32} \mathrm{P}\right]-\mathrm{BP}-\mathrm{dG}-\mathrm{DNA}$ was stu- 


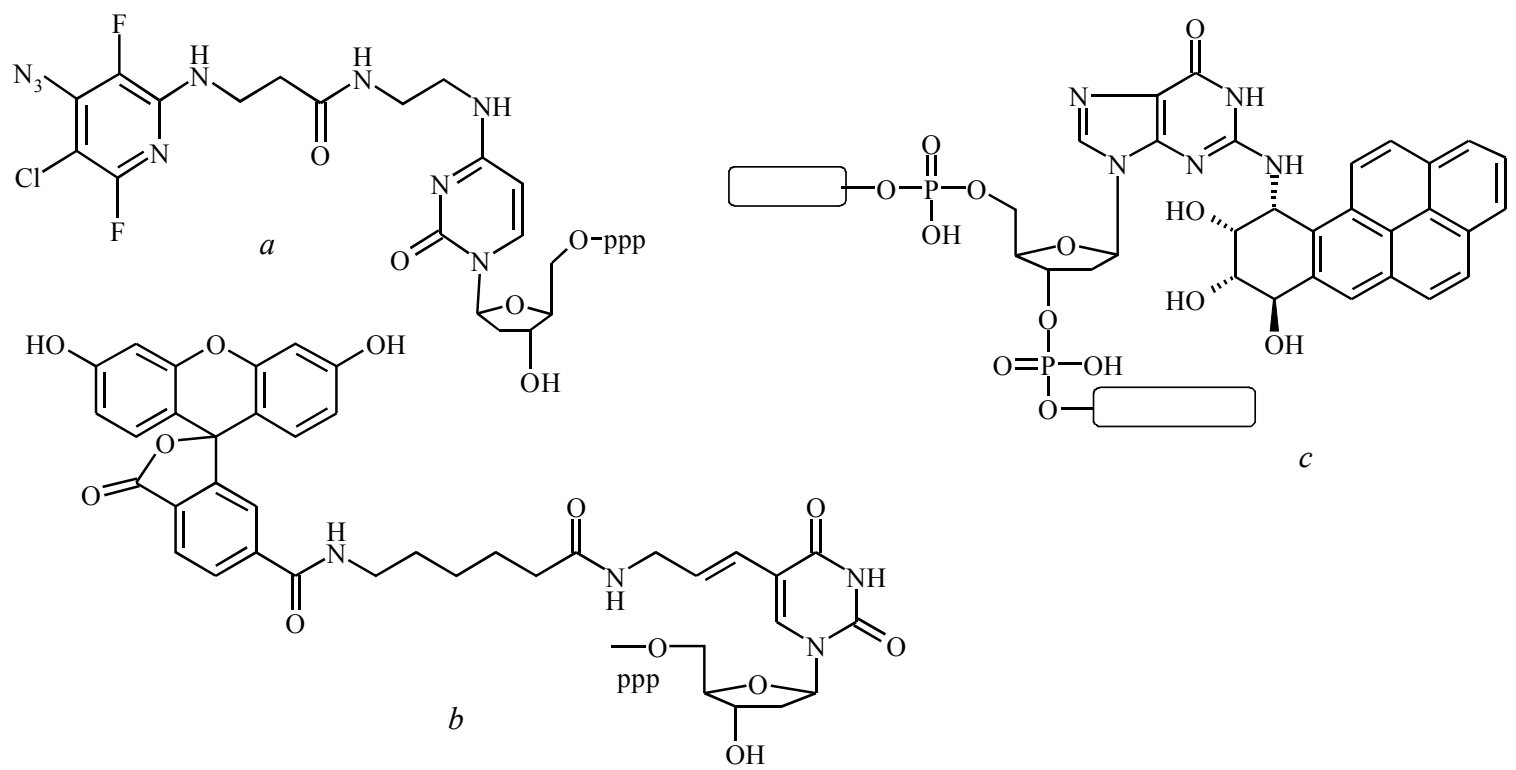

Fig. 1. Model lesions. Structures of Fap-dCTP $(a)$ and Flu-dUTP $(b)$ bearing bulky lesion and the fragment of deoxyribooligonucleotide containing $(+)$-cis-benzo[a]pyrene-N2-deoxyguanosine $(c)$ used for the synthesis of modified DNA chains. BP-modified oligonucleotide has been kindly provided by N. E. Geatsintov (New York University, USA)

died. The reaction mixtures containing $\left[{ }^{32} \mathrm{P}\right]-\mathrm{BP}-\mathrm{dG}-$ DNA were incubated with NER-competent cell extract in the absence or in the presence of equimolar unlabeled competitive Fap-dC- or Flu-dU-DNA. The analysis of samples was carried out as described above.

Results and discussion. Using the improved enzymatic method of synthesis, we have synthesized long Fap-dC- and Flu-dU-DNA (137 bp) and analyzed their properties as substrates for the excision reaction catalyzed by the proteins of NER-competent extract of HeLa cells. BP-dG-DNA (131 bp) synthesized with the respective modified ONT was used as a standard substrate. The structures of model DNAs, containing bulky lesions and schematic representation of the DNA fragments containing modifications are shown in Fig. 1.

The activity of these DNA analogs as NER substrates were demonstrated at the stage of lesion removal. The activity was measured by two methods: direct and indirect detection of the excision products (see Materials and methods). During the direct detection, FapdC-DNA and Flu-dU-DNA contained a ${ }^{32} \mathrm{P}$-label immediately in the damaged nucleotide (on the 3'-side); in the case of BP-DNA, the label was located at a distance of five nucleotides on the 5'-side of the lesion. Thus, excision products (22-32-nucleotide DNA fragments bearing lesions) must contain ${ }^{32} \mathrm{P}$-label. The advantage of this method is the possibility to quantitatively assess lesion removal efficiency without additional stages.

DNA modifications induced by benzo[a]pyrene are one of the most widespread and well-studied types of lesions repaired by NER in humans $[1-3,14]$. This model lesion belongs to a class of systematically studied and rather effective synthetic NER substrates. However, it should be noted that the level of excision in experiments in vitro rarely exceeds $5 \%$ even for such model DNA [13]. During the incubation of $\left[{ }^{32} \mathrm{P}\right]$-BP-DNA with the proteins of NER-competent HeLa extract, radioactive DNA fragments of 22-32 nucleotides were observed in the mixture. The quantity of specific hydrolysis products increased during 10-60 min from the beginning of the reaction. Excised fragments accumulation is also dependent on the concentration of extract proteins in the reaction mixture within the analyzed range of concentrations $(2-15 \mu \mathrm{g} / \mu \mathrm{l})$ (data not shown). Fig. 2, $a$, presents the results of the analysis of reaction mixture after $40 \mathrm{~min}$ of incubation of [ $\left.{ }^{32} \mathrm{P}\right]$-BP-DNA with the extract proteins. The level of excision of damaged fragments from $\left[{ }^{32} \mathrm{P}\right]$-Fap-dC- and $\left[{ }^{32} \mathrm{P}\right]$-Flu-dUDNA was not sufficient to detect the excision reaction by using this method.

Appearance of fragments of typical length from Flu-dU-DNA was detected using the «fill-in» method 
$a$

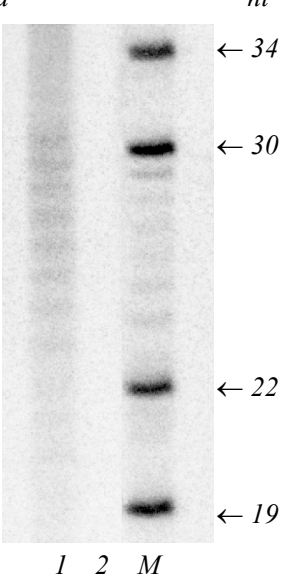

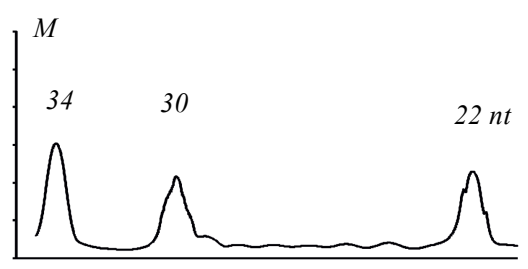

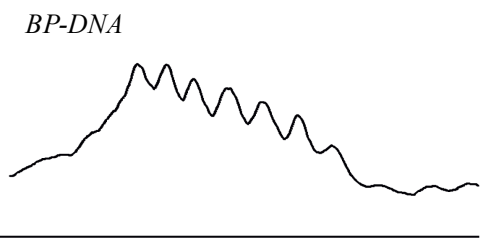

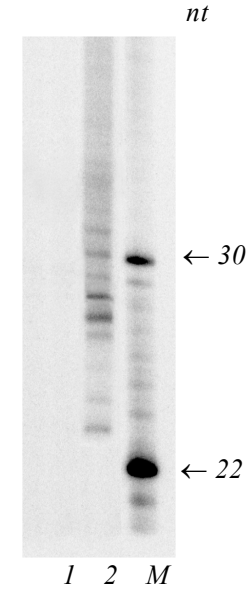

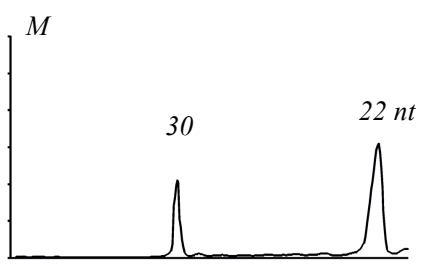

Flu-dU-DNA

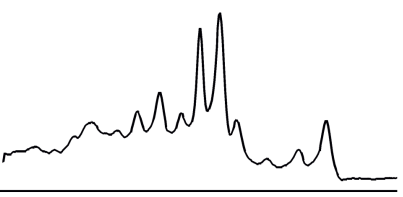

Fig. 2. Radioautographs of gels after separation of excision reaction products: $a$ - direct detection of excision products $(1-$ analysis of reaction mixture containing $20 \mathrm{nM}\left[{ }^{32} \mathrm{P}\right]-\mathrm{BP}-\mathrm{DNA}$ and $7 \mu \mathrm{g} / \mu \mathrm{l}$ of the HeLa extract proteins in $1 \times \mathrm{NER}$ buffer incubated for 40 min at $30{ }^{\circ} \mathrm{C} ; 2-\mathrm{modified}$ duplex incubated without the extract); $b$-indirect detection of excision products; reaction mixtures contained nonradioactive 20 nM Fap-dC-DNA or Flu-dU-DNA and $7 \mu \mathrm{g} / \mu \mathrm{l}$ of the HeLa extract proteins; excision products fused with the respective template were completed using Taq polymerase with $\left[\alpha-{ }^{32} \mathrm{P}\right] \mathrm{dCTP}$ as a substrate ( 1 - unmodified DNA; 2 - Fap-dC-DNA; 3 - Flu-dU-DNA); $M$ - markers of DNA. On the right, $a$ and $b$ panels show the results of densitometric analysis of the radioautographs

(Fig. $2, b)$. Radioactive $\left[\alpha-{ }^{32} \mathrm{P}\right] \mathrm{dCMP}$ was introduced as a label into the removed DNA fragments with damaged nucleotides using DNA-polymerase reaction and complementary template ONT. The advantage of such estimation of substrate properties is higher sensitivity and absence of necessity of synthesis of model DNA with high specific radioactivity. However, products of specific excision from Fap-dC-DNA were not revealed by this method either.

Flu-dU- and Fap-dC-DNA demonstrated the ability for effective competition with BP-DNA for the interaction with proteins of the cell extract excision complex. The experiments (results are shown in Fig. 3) were performed using $\left[{ }^{32} \mathrm{P}\right]-\mathrm{BP}-\mathrm{DNA}$ and nonradioactive competitive DNA duplexes. In the presence of an equimolar amount of the control unmodified duplex, the level of excision for $\left[{ }^{32} \mathrm{P}\right]$-BP-DNA was no less than $95 \%$ of the level of excision observed in the absence of competitive DNA. As a result of adding the equimolar amount of Flu-dU- or Fap-dC-DNA to the reaction mixture, the level of excision of damaged fragments from $\left[{ }^{32} \mathrm{P}\right]-\mathrm{BP}-$ DNA significantly decreased. In the presence of FapdC-DNA, the level of excision from BP-DNA was lower by $20 \%$, while the presence of Flu-dU-DNA reduced the level of BP-DNA specific hydrolysis twofold. Decrease in the quantity of radioactive cleavage products is evidently due to distribution of NER pro- teins between radioactive BP-DNA and nonradioactive Fap-dC- or Flu-dU-DNA.

Our results, in combination with the data of previous studies $[18,19]$, allow us to consider the linear 137-bp Fap-dC-DNA as unrepairable NER substrates. Unrepairable substrate analogs, i. e. structures capable of selective binding of DNA repair proteins but not liable to further processing, are most dangerous for cells. Accumulation of such DNA can considerably reduce the efficiency of the repair machinery due to immobilization of its protein components within nonproductive nucleoprotein complexes [20]. The ability of model lesion to effectively inhibit the repair process in vitro indicates the possibility of its application as a prototype for creation of selective DNA repair inhibitors contributing to the enhancement of efficiency in chemotherapy.

In additional this DNA analog can be applied as effective photoaffinity probe to analyze interaction of NER proteins with bulky DNA lesion. The data speak in favor possibility to use this photoactive DNA to crosslink XPC-HR23B (Fig. 4).

Our preliminary studies with novel non-nucleoside adducts which contain $N$-[6-(9-anthracenylcarbamoyl) hexanoyl]-3-amino-1,2-propandiol and $N$-[6-(5(6)- fluoresceinylcarbamoyl)hexanoyl]-3-amino-1,2-propandiol residues indicated their extremely high substrate pro- 

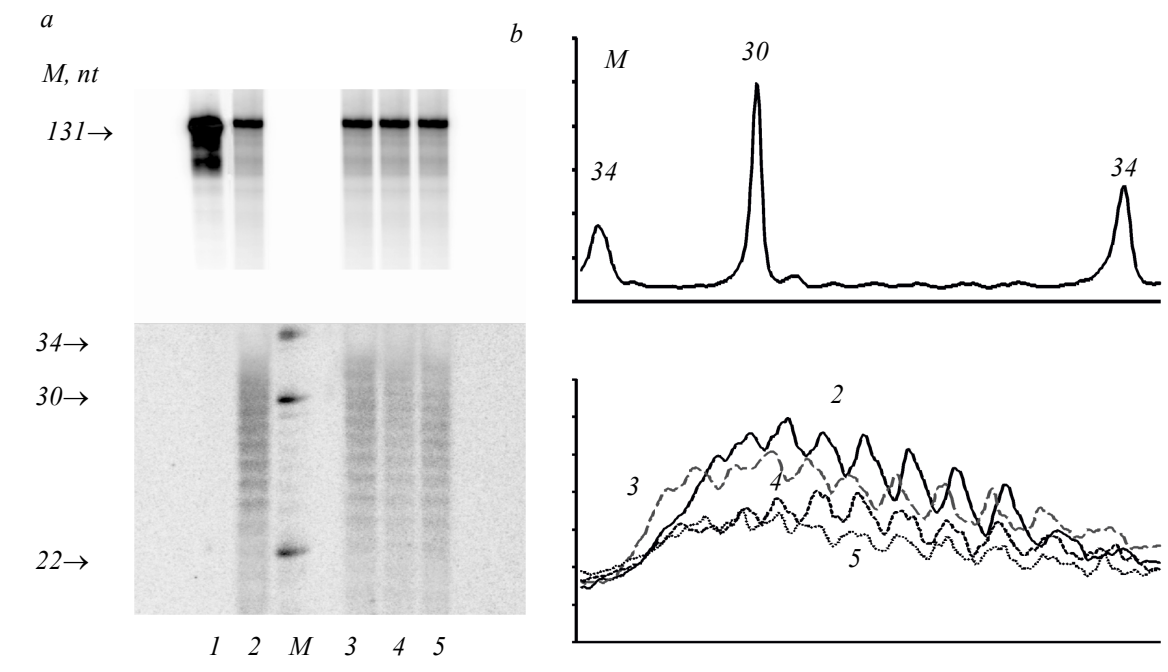

Fig. 3. Radioautograph (a) of gel after separation of excision reaction products by electrophoresis under denaturing conditions $(10 \%$ polyacrylamide gel, $7 \mathrm{M}$ urea). Reaction mixtures containing $20 \mathrm{nM}\left[{ }^{32} \mathrm{P}\right]-\mathrm{BP}-\mathrm{DNA}$ and $1 \times$ NER buffer were incubated for $40 \mathrm{~min}$ at $30{ }^{\circ} \mathrm{C}$ in the absence (2) or presence of $20 \mathrm{nM}$ unlabeled competitive DNA (3 - unmodified duplex; 4 - Flu-dU-DNA; 5 - Fap-dCDNA) and $7 \mu \mathrm{g} / \mu 1$ of the HeLa extract proteins; 1 - results of separation of the mixture containing only unmodified duplex stored with the extract proteins; $M-$ markers of DNA length $(n t) ; b-$ the result of densitometric analysis

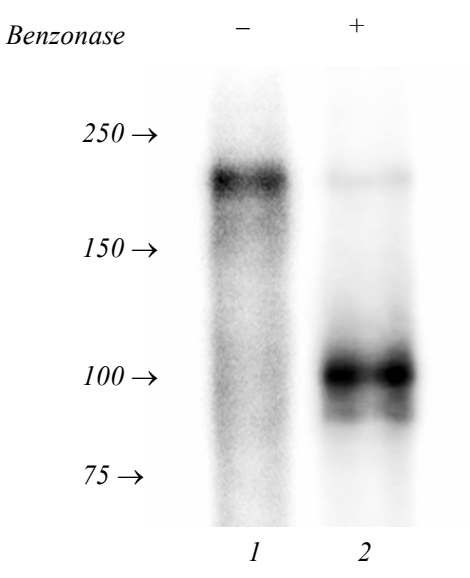

Fig. 4. Radioautograph of gel after separation of proteins to DNA photolinking products. Reaction mixtures contained $10 \mathrm{nM}\left[{ }^{32} \mathrm{P}\right]-\mathrm{Fap}-\mathrm{dC}-$ DNA and 0.5 M XPC-HR23B. The mixtures were exposed to UV radiation at $312 \mathrm{~nm}$ and intensity of $3 \mathrm{~J} / \mathrm{cm}^{2} \cdot \min$ for $5 \mathrm{~min}$. After the UV exposure, aliquots taken from each mixture were treated with benzonase endonuclease ( 1 activity unit per $10 \mu \mathrm{l}$ of a sample, $30 \mathrm{~min}$ at $37^{\circ} \mathrm{C}$ ). The reaction was stopped by heating with the denaturing buffer for protein samples. The buffer for samples was also added to the residual part of the reaction mixture: 1 - sample not treated with benzonase; 2 sample treated with benzonase. Products of photolinking were separated by electrophoresis in $10 \%$ polyacrylamide gel according to Laemmli

perties in NER reaction in vitro. Such model lesion seems to be very promising to study DNA repair mechanism.

To conclude, it should be noted, that developed approach is of general use for the incorporation of NERsensitive distortions into model DNA. Many types of NER substrates can be created by this way, including DNA with photoactivated and fluorescent groups. The new artificial DNA containing bulky non-nucleoside modifications will be useful for fundamental and me- dical research as a tool to detect activity of NER system in cells.

Acknowledgements. This work was supported by the Russian Foundation for Basic Research (project N 1204-00487) and by RAS Program «Molecular and Cellular Biology».

О. М. Свдокимов, О. Ю. Цидулко, І. О. Петрусева, Л. С. Корольова, I. Ю. Серпокрилова, В. М. Сильников, О. І. Лаврик

Синтез модельних ДНК та їхнє застосування як субстратів ексцизійної репарації нуклеотидів

Резюме

Mета. Ексичизійна репарація нуклеотидів (NER) - иче система репарачії ДНК, відповідальна за видалення об 'ємних пошкоджень зі складу ДНК. Такі пошкодження можуть виникати за впливу як опромінення ультрафіолетом, так і факторів довкілля. Вивчення системи NER є вкрай важливим для підвищення ефективності хіміотерапевтичних препаратів. Методи. Використано реакиію NER in vitro ma фотоафінну модификацію. Результати. Синтезовано довгі лінійні ДНК, які імітують субстрати NER, щчо являють собою 137-мірні ДНК-дуплекси і містять у внутрішніх положеннях ланцюгів нуклеотиди із введеними за допомогою спейсерних фрагментів по 4N- i 5C-положеннях dC i dU фторхлоразидопіридильною $і$ флуоресчейновою групами (Fap-dC- i Flu-dU- ДНК), а також ДНК, яка вмішує (+)-ичс-стереоізомер бензо[а] пі рен-N2дезоксигуанозину. Досліджено взаємодію модифікованих ДНКдуплексів з білками NER-компетентного екстракту клітин HeLa. Показано, щзо субстратні властивості модельних ДНК у реакиії специфічної ексиизї̈ змінюються в ряду Fap-dC-ДНК $<<$ Flu-dUДНК $<$ ВP-dG-ДНК. Висновки. Дослідженнями in vitro встановлено, шьо ДНК-аналоги є важливим інструментом для оцінки клітинної репарації. Розроблений підхід виявився універсальним для включення до складу ДНК пошкоджень, які упізнаються системою NER, а також досить перспективним для вивчення механізмів реnараuіï.

Ключові слова: ексцизійна репарація нуклеотидів, модельні ДНК-субстрати. 
А. Н. Евдокимов, А. Ю. Цидулко, И. О. Петрусева, Л. С. Королева, И. Ю. Серпокрылова, В. Н. Сильников, О. И. Лаврик

Синтез модельных ДНК и их применение в качастве субстратов эксиизионной репарации нуклеотидов

Резюме

Цель. Эксиизионная репарация нуклеотидов (NER) - это система репарации ДНК, отвечающая за удаление объемных повреждений из состава ДНК. Такие повреждения могут появляться под воздействием как облучения ультрафиолетом, так и факторов окружающей среды. Изучение системы NER крайне важно для повышения эффективности химиотерапевтических препаратов. Методы. Использованы реакияия NER in vitro и фотоаффинная модификаця. Результаты. Синтезированы протяженные линейные ДНК, имитируюшче субстраты NER, которые представляют собой 137-мерные ДНК-дуплексы, содержащие во внутренних положениях иепей нуклеотиды с введенными с помощью спейсерных фрагментов по $4 N$ - и 5C-положениям dC u dU фторхлоразидопиридильной и флуоресцеиновой группировками (Fap-dC-u Flu-dU-ДНК), а также ДНК, включающая (+)-иис-стереоизомер бензо[a]пирен-N2-дезоксигуанозина. Исследовано взаимодействие модифицированных ДНК-дуплексов с белками NER-компетентно го экстракта клеток HeLa. Показано, что субстратные свойства модельных ДНК в реакции специифической эксиизии меняются в ряду Fap-dC-ДНК << Flu-dU-ДНК < BP-dG-ДНК. Выводы. Исследованиями in vitro установлено, что ДНК- аналоги являются важным инструментом для оченки клеточной репарации. Разработанный подход оказался универсальным для включения в состав ДНК повреждений, узнаваемых системой NER, а также достаточно перспективным для изучения механизмов репарации.

Ключевые слова: эксиизионная репарация нуклеотидов, модельные ДНК-субстраты.

\section{REFERENCES}

1. Scharer O. D. Chemistry and biology of DNA repair // Angew. Chem. Int. Ed. Engl.-2003.-42, N 26.-P. 2946-2974.

2. Dip R., Camenisch U., Naegeli H. Mechanisms of DNA damage recognition and strand discrimination in human nucleotide excision repair // DNA Repair (Amst).-2004.-3, N 11.-P. 1409-1423.

3. Gillet L. C., Scharer O. D. Molecular mechanisms of mammalian global genome nucleotide excision repair // Chem. Rev.-2006.106, N 2.-P. 253-276.

4. Sugasawa K., Okamoto T., Shimizu Y., Masutani C., Iwai S., Hanaoka $F$. A multistep damage recognition mechanism for global genomic nucleotide excision repair // Genes Dev.-2001.-15, N 5.-P. 507-521.

5. Hey T., Lipps G., Sugasawa K., Iwai S., Hanaoka F., Krauss G. The XPC-HR23B complex displays high affinity and specificity for damaged DNA in a true-equilibrium fluorescence assay // Biochemistry.-2002.-41, N 21.-P. 6583-6587.

6. Tapias A., Auriol J., Forget D., Enzlin J. H., Scharer O. D., Coin F., Coulombe B., Egly J. M. Ordered conformational changes in damaged DNA induced by nucleotide excision repair factors // J. Biol. Chem.-2004.-279, N 18.-P. 19074-19083.
7. DellaVecchia M. J., Croteau D. L., Skorvaga M., Dezhurov S. $V$., Lavrik O. I., Van Houten B. Analyzing the handoff of DNA from UvrA to UvrB utilizing DNA-protein photoaffinity labeling // J. Biol. Chem.-2004.-279, N 43.-P. 45245-45256.

8. Trego K. S., Turchi J. J. Pre-steady-state binding of damaged DNA by XPC-hHR23B reveals a kinetic mechanism for damage discrimination // Biochemistry.-2006.-45, N 6.-P. 1961-1969.

9. Huang J. C., Sancar A. Determination of minimum substrate size for human excinuclease // J. Biol. Chem.-1994.-269, N 29.P. 19034-19040.

10. Reardon J. T., Sancar A. Purification and characterization of Escherichia coli and human nucleotide excision repair enzyme systems // Methods Enzymol.-2006.-408.-P. 189-213.

11. Buterin T., Meyer C., Giese B., Naegeli H. DNA quality control by conformational readout on the undamaged strand of the double helix // Chem. Biol.-2005.-12, N 8.-P. 913-922.

12. Sugasawa K., Akagi J., Nishi R., Iwai S., Hanaoka F. Two-step recognition of DNA damage for mammalian nucleotide excision repair: directional binding of the XPC complex and DNA strand scanning // Mol. Cell.-2009.-36, N 4.-P. 642-653.

13. Mocquet V., Kropachev K., Kolbanovskiy M., Kolbanovskiy A., Tapias A., Cai Y., Broyde S., Geacintov N. E., Egly J. M. The human DNA repair factor XPC-HR23B distinguishes stereoisomeric benzo[a]pyrenyl-DNA lesions // EMBO J.-2007.-26, N 12.P. 2923-2932.

14. Kropachev K., Kolbanovskii M., Cai Y., Rodriguez F., Kolbanovskii A., Liu Y., Zhang L., Amin S., Patel D., Broyde S., Geacintov $N$. E. The sequence dependence of human nucleotide excision repair efficiencies of benzo[a]pyrene-derived DNA lesions: insights into the structural factors that favor dual incisions // J. Mol. Biol.-2009.-386, N 5.-P. 1193-1203.

15. Dezhurov S. V., Khodyreva S. N., Plekhanova E. S., Lavrik O. I. A new highly efficient photoreactive analogue of dCTP. Synthesis, characterization, and application in photoaffinity modification of DNA binding proteins // Bioconjug. Chem.-2005.-16, N 1.-P. 215-222.

16. Nishi R., Okuda Y., Watanabe E., Mori T., Iwai S., Masutani C., Sugasawa K., Hanaoka F. Centrin 2 stimulates nucleotide excision repair by interacting with xeroderma pigmentosum group $\mathrm{C}$ protein // Mol. Cell. Biol.-2005.-25, N 13.-P. 5664-5674.

17. Evdokimov A. N., Petruseva I. O., Pestryakov P. E., Lavrik O. I. Photoactivated DNA analogs of substrates of the nucleotide excision repair system and their interaction with proteins of NERcompetent extract of HeLa cells. Synthesis and application of long model DNA // Biochemistry (Mosc).-2011.-76, N 1.-P. 157-166.

18. Petruseva I. O., Tikhanovich I. S., Chelobanov B. P., Lavrik O. I. RPA repair recognition of DNA containing pyrimidines bearing bulky adducts // J. Mol. Recognit.-2008.-21, N 3.-P. 154-162.

19. Petruseva I. O., Tikhanovich I. S., Maltseva E. A., Safronov I. $V$., Lavrik O. I. Photoactivated DNA analogs of substrates of the nucleotide excision repair system and their interaction with proteins of NER-competent HeLa cell extract // Biochemistry (Mosc).-2009.-74, N 5.-P. 491-501.

20. Buterin T., Hess M. T., Gunz D., Geacintov N. E., Mullenders L. $H$., Naegeli $H$. Trapping of DNA nucleotide excision repair factors by nonrepairable carcinogen adducts // Cancer Res.-2002.62, N 15.-P. 4229-4235. 